\title{
Sistem Pemasaran Kayu Rakyat di Kabupaten Bulukumba Sulawesi Selatan
}

\author{
Muh. Erwin Syah ${ }^{1},{\text { Makkarennu }{ }^{2} \text {, Supratman }}^{2}$ \\ ${ }^{1}$ Mahasiswa Fakultas Kehutanan, Universitas Hasanuddin \\ ${ }^{2}$ Staf Pengajar Departemen Kehutanan, Fakultas Kehutanan, Universitas Hasanuddin \\ *Email: nmakkarennu@gmail.com
}

\begin{abstract}
This study aims to identify marketing channels and analyze the marketing system. The results of this study are expected to be a study material for the improvement of community forest management in Bulukumba regency, South Sulawesi province, in an effort to improve the welfare of the community, especially forest farmers. The research was conducted in two villages belonging to the Association of People's Wood Management: Karassing Village, Herlang Subdistrict, and Sapobonto Village, Bulukumpa Subdistrict, Bulukumba Regency. Data collection was conducted by semistructured interviews on marketing actors with snowball method (chain), field survey related to marketing institution, then analyzed by using SCP (structural, conduct, performance) method. From the results of the research, there are three channels of marketing identification: 1) Farmer - Collector - Sawmill Industry - Retail Trader; 2) Farmers - Sawmill Industry Retail Traders; and 3) APKAR - Wood Processing Industry. The wood marketing system found in APKAR farmers has not been efficient because the overall market structure tends to Oligopsoni, and market behavior that tends to be controlled by the sawmill industry.
\end{abstract}

Keywords: Efisiensi; hutan rakyat; pemasaran; saluran pemasaran; kayu gergajian

\section{PENDAHULUAN}

Masa kejayaan industri perkayuan di Indonesia pada periode 1980 sampai akhir tahun 1990-an telah lewat, dimana pada era itu industri kayu memberikan kontribusi nyata bagi perekonomian Indonesia baik dari penyerapan tenaga kerja, pemasukan devisa dan penciptaan peluang usaha. Alviya, (2011) juga menyatakan bahwa industri perkayuan tercatat pernah menjadi barometer peningkatan penerimaan Negara sektor kehutanan selama periode 1967-1999.

Saat ini, industri perkayuan menghadapi berbagai macam tantangan. Salah satu permasalahan utama yang dihadapi oleh industri perkayuan Indonesia adalah berkurangnya pasokan bahan baku kayu dari hutan alam (Departemen Kehutanan, 2007). Hutan alam yang ada saat ini belum bisa memenuhi kebutuhan bahan baku kayu sehingga dibutuhkan pasokan bahan baku kayu dari sumber lain serta waktu yang cukup lama untuk pemanfaatannya (Makkarennu dan Nakayasu, 2013). Istoto dan Listyanto (2009) juga menyatakan bahwa selain kekurangan bahan baku, daya saing produk dan nilai tambah yang rendah merupakan sejumlah permasalahan yang dihadapi industri perkayuan saat ini. Di sisi lain perkembangan industri perkayuan juga terkendala masalah pemasaran khususnya pasar ekspor (Dwiprabowo, 2009).

Hutan rakyat dan hutan tanaman rakyat diakui sebagai salah satu solusi permasalahan kehutanan di Indonesia (Widarti, 2015). Pembangunan dan penyempurnaan tata usaha kayu hutan rakyat menjadi salah satu solusinya. Untuk itu sistem pengelolaan tidak saja dititik beratkan pada peningkatan produksi, namun mengarah pada peningkatan taraf hidup petani, perluasan lapangan kerja bahkan jika memungkinkan juga bertujuan untuk memperluas pasar produk (Tukan, 2000). Sifat dari hasil produksi hutan rakyat (kayu rakyat) di antaranya volume atau jumlahnya yang relatif kecil, jauh dari konsumen/pabrik dan industri kayu lainnya, kualitas kayu yang relatif lebih rendah dibandingkan dengan kualitas yang diharapkan serta kurangnya informasi mengenai harga kayu dipasaran seringkali menjadi persoalan terhadap kurang maksimalnya petani hutan rakyat dalam memperoleh keuntungan (Octaviani dalam Rosnawati 2004). Untuk itu tentunya dibutuhkan sistem pengelolaan yang baik, dan salah satunya adalah keberadaan lembaga pengelola atau unit manajemen.

Kabupaten Bulukumba adalah salah satu daerah di Sulawesi Selatan yang memiliki potensi hutan rakyat yang cukup besar. Berdasarkan data dari Dinas Kehutanan Kabupaten Bulukumba mencatat luas hutan rakyat $22.500 \mathrm{Ha}$ yang tersebar di Sembilan kecamatan, dengan lembaga atau unit manejemen Asosiasi Pengelola Kayu Rakyat (APKAR). Sebagai unit manajemen salah satu peran APKAR adalah bagaimana 
mendorong peningkatan pendapatan petani dari segi pemasaran. Untuk itu penting kiranya untuk dilakukan penelitian tentang sistem pemasaran kayu rakyat menlalui Asosiasi Pengelola Kayu Rakyat di Kabupaten Bulukumba sebagai bahan kajian dalam peningkatan kesejahteraan masyarakat setempat.

Penelitian ini bertujuan untuk mengidentifikasi saluran pemasaran dan menganalisis sistem pemasaran kayu rakyat yang tergabung dalam Asosiasi Pengusaha Kayu Rakyat (APKAR). Hasil dari penelitian ini diharapkan dapat menjadi bahan kajian dan rekomendasi untuk perbaikan tata kelola hutan rakyat di Kabupaten Bulukumba, Provinsi Sulawesi Selatan dalam upaya peningkatan kesejahteraan masyarakat khususnya petani hutan.

\section{METODE PENELITIAN}

\subsection{Metode Pengumpulan Data}

Pengumpulan data pada penelitian ini menggunakan tiga metode utama, yaitu wawancara, identifikasi langsung, dan studi kepustakaan. Wawancara dilakukan terhadap pihak-pihak yang terlibat dalam topik penelitian, seperti petani, pedagang pengumpul, industry penggergajian, dan pedagang pengecer. Observasi; Identifkasi langsung dengan cara mengamati secara langsung dan verifikasi terhadap kondisi yang ada di lapangan. Proses identifikasi dilakukan untuk mengetahui mekanisme pemasaran. Studi kepustakaan; Studi pustaka dilakukan untuk mendapatkan informasi yang akan diperoleh dari bahan pustaka, hasil penelitian terdahulu, maupun dokumen dari instansi terkait.

\subsection{Analisis Data}

Data yang diperoleh dianalisis secara kualitatif dan kuantitatif guna menjawab semua tujuan yang di inginkan. Saluran pemasaran dapat dianalisis dengan melakukan pengamatan terhadap pelaku pemasaran. Setiap pelaku pemasaran akan membentuk saluran pemasaran yang berbeda, yang akan mempengaruhi besarnya bagian harga yang diterima oleh setiap pelaku. Efisiensi sistem pemasaran kayu rakyat dianalisis melalui pendekatan SCP (Structure, Conduct, Performance). Dengan menggunakan metode SCP, efisiensi pemasaran kayu dapat dilihat dari struktur pasar, perilaku pasar, dan Kinerja pasar yang terjadi.

\section{a. Structure (Struktur Pasar)}

Analisis struktur pasar ditujukan untuk mengetahui kondisi persaingan diantara produsen dan konsumen kayu yang terdapat di wilayah penelitian. struktur pasar dianalisis dengan melihat jumlah pembeli dan penjual, hambatan keluar masuk pasar, dan diferensiasi produk.

\section{b. Conduct (Perilaku Pasar)}

Perilaku pasar menunjukkan tingkah laku perusahaan dalam struktur pasar tertentu, terutama bentuk-bentuk keputusan apa yang harus diambil dalammenghadapi berbagai struktur pasar. Perilaku pasar dianalisis dengan melihat :

1. Penentuan harga: yaitu bagaimana pembentukan harga yang terjadi pada pasar

2. Kerja sama antar pedagang : praktek kerja sama antara pedagang terhadap penyebar luasan informasi pasar

c. Performance (Kinerja Pasar)

Kinerja pasar dianalisis dengan melihat: 
1. Margin pemasaran, yaitu Margin pemasaran adalah perbedaan harga yang dibayar oleh konsumen akhir untuk suatu produk dengan harga yang diterima produsen untuk produk yang sama. Secara matematis sebagai berikut :

$\mathrm{Mp}=\mathrm{Pf}-\mathrm{Pr}$, dimana

$\mathrm{Mp}$ : Margin pemasaran

$\operatorname{Pr}:$ Harga produsen

Pf : Harga konsumen

2. Rasio keuntungan dan biaya, yaitu nilai dari keuntungan yang diperoleh dibandingkan dengan biaya pemasaran yang dikeluarkan oleh setiap lembaga pemasaran.

Rasio keuntungan $/$ biaya $=\frac{\pi i}{\mathrm{Ci}}$

\section{HASIL DAN PEMBAHASAN}

\subsection{Saluran Pemasaran Kayu Rakyat}

Analisis saluran pemasaran merupakan identifikasi terhadap aliran barang dari produsen ke konsumen, dengan melihat lembaga pemasaran yang terlibat pada proses pemindahan kayu hutan rakyat dari petani sebagai produsen hingga ke konsumen. Saluran pemasaran untuk jenis kayu rakyat sengon secara dominan ditemukan pada pemasaran kayu Kabupaten Bulukumba dapat menggambarkan jalur pemasaran dan model pemasaran beberapa jenis kayu lainnya. Secara umum pemasaran kayu rakyat petani APKAR terbagi atas dua yaitu pemasaran yang dilakukan tanpa APKAR dan pemasaran melalui kelembagaan APKAR. Pemasaran tanpa APKAR merupakan pemasaran kayu yang dilakukan oleh petani seacara sendiri-sendiri, yakni petani memasarkan kayunya langsung ke pihak industri dalam hal ini industri penggergajian ataupun melalui pengumpul tingkat desa. Semetara pemasaran kayu melalui APKAR, pengelolaan dan mekanismenya di atur oleh pihak APKAR.

Dari hasil yang diperoleh pada dua desa, pemasaran yang dilakukan melalui kelembagaan APKAR hanya tiga kali penjualan, dua penjualan pada Desa Karassing dan satu kali penjualan pada Desa Sapobonto. Hal tersebut dikarenakan petani menganggap mekanisme pemasaran melalui APKAR terbilang rumit dan hasil penjualan kayu yang diperoleh tidak jauh berbeda dengan penjualan secara sendiri-sendiri. Persentase penjualan jenis saluran pemasaran dapat dilihat pada tabel di bawah ini

Tabel 1. Presentase penjualan kayu sengon pada setiap saluran

\begin{tabular}{|r|c|c|c|c|}
\hline No. & Desa & Saluran 1 & Saluran 2 & Saluran 3 \\
\hline 1 & Karassing & 4 & 4 & 2 \\
\hline 2 & Sapobonto & 7 & 2 & 1 \\
\hline & Total & 11 & 6 & 3 \\
\hline \multicolumn{2}{r|r|}{} \\
\end{tabular}

\subsubsection{Lembaga Pemasaran Kayu Rakyat}

\section{a. Petani Kayu Rakyat}

Sebagian besar dari petani hutan rakyat pada lokasi penelitian menerapkan pola agroforestri dalam mengelola lahannya. Selain jenis tanaman kayu, tanaman pertanian dijadikan tanaman sela yang hasilnya 
dimanfaatkan untuk kebutuhan sehari-hari. Secara keseluruhan, jenis yang paling banyak ditanam oleh petani adalah jenis sengon. Menurut pengakuan responden, sengon merupakan tanaman yang cepat tumbuh dan mudah untuk dibudidayakan sehingga tidak membutuhkan waktu lama untuk dapat memanennya. Petani biasanya mulai menjual pohon sengonnya pada umur 4-6 tahun dengan diameter di atas $20 \mathrm{~cm}$. Selain itu, tidak ada perlakuan khusus oleh petani pada sengon sehingga biaya yang dikeluarkan oleh petani tidak besar. Terdapat 3 sistem penjualan kayu yang dilakukan oleh para petani diantaranya adalah per pohon, borongan (hamparan), dan per kubikasi, sedangkan sistem penebangan yang ditemui selama penelitian ada 2, yaitu tebang habis dan tebang pilih. Sistem penjualan tebang pilih sering dikenal juga dengan sistem penjualan tebang butuh. Disebut tebang butuh karena pada kenyataannya pohon-pohon tersebut lebih dianggap tabungan oleh pemiliknya dan tidak akan dijual sebelum ada keperluan yang mendesak. Petani biasanya menjual pohonnya saat membutuhkan biaya untuk sekolah anak ataupun biaya lain yang mendesak.

\section{b. Pedagang pengumpul kayu rakyat}

Pedagang pengumpul merupakan pelaku pemasaran yang bertindak sebagai perantara diantara petani hutan rakyat, industri penggergajian (sawmill), ataupun konsumen lainnya. Pedagang pengumpul biasanya membeli kayu pada petani dengan harga yang didasarkan pada volume taksiran pengumpul. Namun pada kenyataannya, taksiran volume yang dijadikan dasar dalam penentuan pembelian kayu seringkali lebih menguntungkan pihak pedagang pengumpul.

\section{c. Industri Sawmill (Penggergajian)}

Industri sawmill (penggergajian) merupakan industri pengolahan kayu rakyat dari kayu bulat menjadi kayu gergajian seperti balok, papan, dan lain-lain. Untuk pemenuhan pasokan bahan baku industri penggergajian biasanya bekerja sama dengan pedagang pengumpul sebagai perantara terhadap petani, namun terkadang juga industri membeli langsung kepada petani.

\section{d. Pedagang Eceran}

Pedagang eceran merupakan pedagang kayu gergajian seperti balok, papan, dan lain-lain pada tingkatan kecematan atau kabupaten. Pedagang eceran memperoleh pasokan kayu dari industri penggergajian.

\subsubsection{Saluran Pemasaran Petani tanpa Melalui APKAR}

Saluran pemasaran kayu petani tanpa melalui APKAR merupakan pemasaran kayu yang dilakukan oleh petani APKAR namun tidak melalui mekanisme yang diterapkan di APKAR, atau dengan kata lain petani memasarkan kayunya dengan cara sendiri-sendiri. Pemasaran secara sendiri-sendiri dianggap lebih praktis dibandingkan pemasaran melalui APKAR, petani bisa menjual kayunya dengan cara dan bentuk yang sesuai dengan keinginan dan kebutuhan petani.

Pemasaran kayu rakyat tanpa melalui APKAR terdiri dari dua saluran yaitu, seperti yang terihat pada gambar di bawah ini :

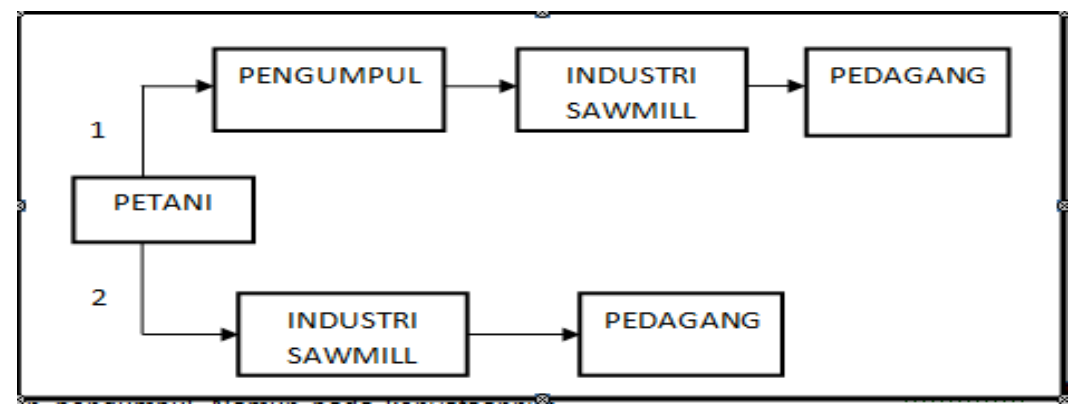

Gambar 1. Saluran Pemasaran Kayu Rakyat Tanpa melalui APKAR 
Saluran (1) yaitu pemasaran kayu hutan rakyat dari petani ke pedagang pengumpul, kemudian ke industri penggergajian lalu ke padagang pengecer. Penjualan dengan jenis ini relatif murah karena petani belum sampai kepada proses pemotongan kayu atau pembentukan kayu, sehingga tidak ada bentuk pasti atau harga pasti mengenai kayu tersebut, seringkali petani menjual kayunya dengan bentuk penjualan perpohon dengan sistem tebang pilih. Harga ditentukan dengan cara kesepakatan saja dengan menggunakan ukuran hanya dengan taksiran pedagang pengumpul. Akan tetapi $55 \%$ petani responden lebih memilih menjual hasil panennya langsung kepada pedagang pengumpul karena dianggap lebih mudah dalam hal pemasaran.

Selajutnya pengumpul menjual kayu kepada industri penggergajian (sawmill), dengan bentuk kayu bulat (bantalan). Pada proses selanjutnya industri penggergajian (sawmill) menjual ke pedagang eceran dengan bentuk kayu gergajian atau balok.

Saluran (2) yaitu pemasaran kayu rakyat dari petani ke industri penggergajian (sawmill) lalu ke pedagang eceran. Pada proses ini petani hutan rakyat menjual kayu hasil panennya kepada industri penggergajian tanpa pihak perantara atau pedagang pengumpul, penjualan secara langsung relatif lebih menguntungkan dibandingkan melalui pedagang pengumpul. Akan tetapi tidak semua petani menyukai penjualan seperti ini hanya $30 \%$ dari petani responden, karena pihak industri penggergajian hanya membeli kayu dari petani dengan bentuk borongan (Hamparan) atau kubikasi. Selanjutanya pihak industri penggergajian menjual ke pedagang pengecer dengan bentuk kayu gergajian atau balok.

\subsubsection{Saluran Pemasaran Kayu Rakyat Melalui APKAR}

Pada saluran pemasaran kayu rakyat melalui APKAR tentunya harus sesuai dengan mekanisme yang disepakati pada kelembagaan APKAR, yang terdiri atas pengelolaan, penebangan, dan pemasaran serta harus sesuai dengan Prosedur Standar Pelaksanaan (PSP) APKAR. Dalam hal pemasaran pihak APKAR telah membentuk tim yang menangani sistem pemasaran. Jadi, petani cukup menginformasikan kepada tim pemasaran mengenai kayu yang dimilikinya. Sebagai fasilitator pemasaran, pihak APKAR yang mengatur transaksi jual beli dengan mitra tetap dalam hal ini industi pengolahan kayu.

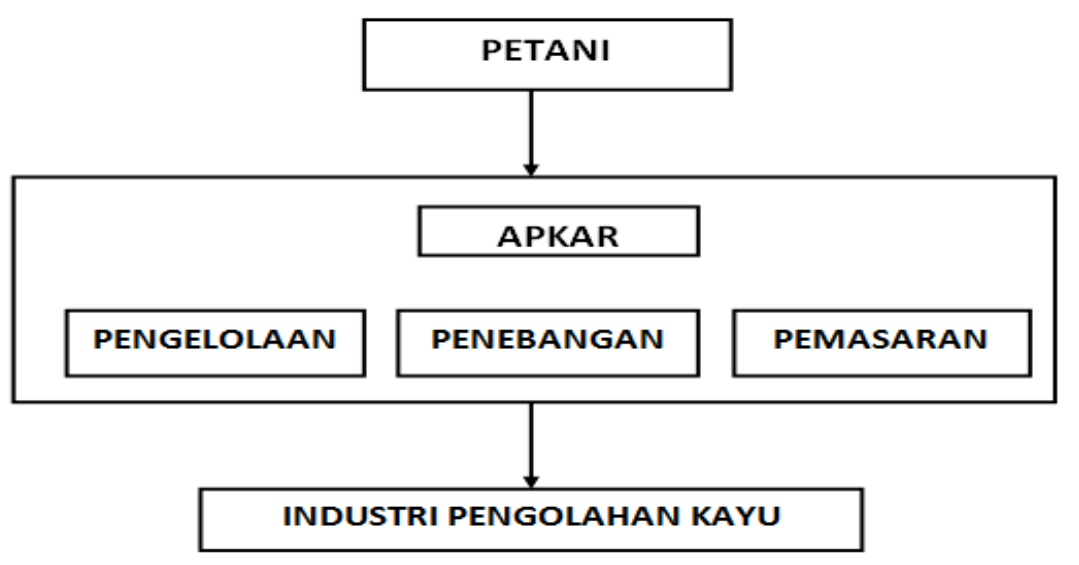

Gambar.2 Jalur Pemasaran Petani Hutan Tergabung dalam APKAR

Petani beranggapan bahwa mekanisme penebangan dan syarat penjualan kayu sangat sumit sebagaimana yang tercantum dalam PSP APKAR dibawah ini :

a. Sebelum melakukan penebangan (tebang pemanenan), pemilik harus melapor kepada Koordinator Desa/ Ketua Kelompok setempat untuk proses selanjutnya.

b. Koordinator Desa harus memastikan adanya bukti legalitas pemilikan tanah pada pohon yang akan ditebang, serta melihat kesesuaian dengan data potensi hutan dan jatah tebang yang ada. 
c. Setelah pohon ditebang, untuk keperluan perdagangan dan/atau pengangkutan, pemilik kayu yang difasilitasi oleh Pengurus APKAR, mengajukan permohonan penerbitan dokumen angkutan kayu berdasarkan aturan penatausahaan hasil hutan kayu yang berlaku.

d. $\quad$ Proses Penerbitan SKAU oleh Pejabat Penerbit SKAU di Desa / penerbit dari internal APKAR yang telah berkualifikasi atau Dinas Kehutanan Kabupaten Bulukumba sesuai dengan ketentuan yang sudah diatur oleh Pemerintah.

e. Pengangkutan kayu hanya dapat dilakukan setelah dilengkapi dengan dokumen angkutan berdasarkan aturan yang berlaku.

Sebagai lembaga atau asosiasi, APKAR menginginkan bagaimana hutan dan hasil hutan terkelola secara baik dan benar, pemberian kepastian hukum serta terwujudnya peningkatan kesejahteraan masyarakat pengelola kayu rakyat. Namun dilihat dari sisi ekonomi belum memperlihatkan adanya peningkatan nilai jual (belum menguntungkan pihak masyarakat sebagai pelaku utama dilapangan, kalaupun ada yang diuntungkan baru pihak yang lain, diantaranya adalah lembaga sertifikasi / lembaga audit, pelaksana program dan lain-lain). Pada umumnya petani hutan rakyat sudah merasa nyaman dengan kebiasaan tanpa mengikuti aturan Penata Usahaan Hasil Hutan (PUHH).

\subsection{Analisis Efisiensi Pemasaran Kayu Rakyat}

Efisiensi pemasaran kayu rakyat dapat dianalisis dengan melihat bagaimana struktur, perilaku, dan kinerja pasar yang terjadi serta bagaimana keterkaitan dan saling pengaruhnya.

\subsubsection{Struktur Pasar}

Struktur pasar merupakan penampakan karakteristik pasar dengan melihat Jumlah lembaga pemasaran dan hambatan masuk pasar, serta diffrensiasi produk.

\section{a. Jumlah Lembaga Pemasaran dan Hambatan Masuk Pasar}

Salah satu indikator dalam melihat struktur pasar adalah jumlah lembaga pemasaran. Dari sudut penjual (petani), berdasarkan perbandingan jumlah petani dengan pedagang pengumpul, dapat dikatakan bahwa struktur pasar yang terbentuk adalah oligoposoni. Hal ini disebabkan karena jumlah petani $(58,5 \%)$ yang jauh lebih besar dari pedagang pengumpul kayu $(13,8 \%)$ dan produk yang diperjual belikan bersifat homogen, selain itu hambatan keluar masuk pasar pada tingkat petani juga lebih rendah dibandingkan dengan peadagang pengumpul. Dengan demikian petani tidak bisa memegang kendali terhadap penentuan harga.

Pada tingkat pemasaran selanjutnya jumlah pedagang kayu lebih banyak daripada industri penggergajian (sawmill) (7,7\%). Dengan demikian struktur pasar yang terbentuk yaitu monopsoni. Hambatan untuk masuk sebagai pelaku pasar baru lebih tinggi karena membutuhkan sejumlah kapital/modal yang besar.

Tabel 2. Jumlah Pelaku Pasar

\begin{tabular}{|c|l|c|c|}
\hline No & \multicolumn{1}{|c|}{ Pelaku Pasar } & Jumlah (n) & Persen (\%) \\
\hline 1 & Petani & 38 & 58.46 \\
\hline 2 & Pedagang pengumpul & 9 & 13.84 \\
\hline 3 & Sawmill & 5 & 7.69 \\
\hline 4 & Pedagang kayu (eceran) & 7 & 10.76 \\
\hline 5 & Pembuat Perabotan & 4 & 6.15 \\
\hline 6 & Industri Pengolahan Kayu & 2 & 3.07 \\
\hline \multicolumn{2}{r|}{ Jumlah } & 65 & $100 \%$ \\
\hline
\end{tabular}


Pada tingkat pedagang kayu, jumlah industri sawmill (penggergajian) hampir sama dengan pedagang kayu dan pembuat perabotan sehingga dalam pemenuhan pasokan bahan baku pedagang kayu maupun perabotan tergantung pada industri penggergajian. Struktur pasar yang terbentuk adalah pasar oligopoly, yaitu dimana pasokan bahan bahan baku kayu dikuasai oleh industri penggergajian. Selain itu industri penggergajian mempunyai pilihan pemasaran ke luar daerah, sehingga pasar cenderung dikuasai oleh industri penggegajian.

Dengan demikian dapat disimpulkan bahwa struktur pasar terbentuk berdasarkan jumlah antar lembaga pemasaran dan petani adalah struktur persaingan tidak sempurna.

\section{b. Diferensiasi produk}

Produk awal adalah berupa kayu pohon, kemudian dikumpulkan oleh pedagang pengumpul atau industri penggergajian kemudian diolah menjadi produk kayu barel (gergajian), begitu pula oleh pedagang kayu diproses dengan teknologi sederhana dan menghasilkan kayu siap jual. Produk kayu yang dihasilkan industri penggergajian ini mempunyai jaringan pasar yang luas meliputi pasar lokal maupun domestik. Dari setiap lembaga pemasaran yang bersaing terlihat bahwa pasar bersifat homogen dan tidak mempunyai diferensiasi produk disetiap pelaku pemasaran.

\subsubsection{Conduct (Perilaku Pasar)}

\section{a. Penentuan Harga}

Berdasarkan hasil penelitian diketahui bahwa dalam proses penentuan harga petani sebagai pihak penerima (price taker), ini terlihat dari sruktur pasar yang terbentuk jumlah petani jauh lebih besar dari pedagang pengumpul. Salah satu faktor juga yang menyebabkan petani sebagai price taker yakni kurangnya pengetahuan petani terkait kondisi harga diperadaran, serta kadang kala desakan kebutuhan hidup yang membuat posisi tawar petani menjadi lemah.

Pada tingkatan pedagang pengumpul, harga penjualan kayu ditentukan oleh industri sawmill. Begitupun pada tingkatan selanjutnya, yaitu dari industri sawmill ke pedagang eceran maupun ke pedagang perabotan. Selanjutnya untuk industri pengolahan lanjutan biasanya penetapan harga ada pada pihak industri yang selanjutnya berhubungan dengan pedagang pengumpul ataupun langsung ke pihak petani. Dari praktekpenetapan harga yang terlihat secara umum sebenarnya yang menguasai pasar adalah industri sawmill, hal tersebut disebabkan karena industri sawmill sebagai pemasok bahan baku kayu olahan mempunyai pilihan pemasaran ke luar daerah dengan standar harga yang lebih tinggi dari pasar lokal.

Perilaku pasar terjadi karena adanya pihak yang ingin memaksimalkan profit, yaitu pada penentuan harga lebih banyak ditentukan oleh satu pihak, biasanya dilakukan oleh pihak penjual dan tidak adanya kerjasama dengan konsumen dalam penentuan harga. Sedangkan perilaku konsumen memiliki kepentingan khusus dengan berbagi alasan berusaha mempengaruhi atau mengubah pikiran penjual untuk memenuhi kepentingan utamanya yaitu mendapatkan barang yang diinginkan.

Kemudian untuk sistem pembayaran yang dilakukan pedagang selain secara tunai, juga terkadang dilakukan secara berjangka atau setelah petani meyetorkan hasil kayu ke Industri. Apabila petani menjual hasil panennya langsung ke pabrik, maka petani menanggung biaya penebangan dan biaya angkut, tetapi apabila petani menjual ke pedagang pengumpul, maka petani tidak menanggung biaya penebangan dan biaya angkut tersebut.

\section{b. Kerjasama antar Pedagang}

Praktek kerjasama antar lembaga pemasaran di daerah penelitian terbatas pada informasi harga yang kurang terbuka, artinya tidak semua petani mengetahui secara pasti spesifikasi jenis dan kualitas kayu, dan harga kayu di pasaran. Mereka menentukan harga dengan info sederhana dari sesama petani, dan para 
pengumpul terikat dengan industri sawmiil ataupun dengan perusahaan pengelola kayu. Kerjasama yang kurang membuat harga kayu dari segi petani lebih murah.

\subsubsection{Performance (Kinerja Pasar)}

Berdasarkan kepada kriteria Kohls, (1967), yaitu suatu sistem pemasaran disebut efisien jika mampu menyampaikan produk atau jasa dari produsen ke konsumen dengan biaya yang semurah-murahnya dan adanyapembagian yang merata dari harga yang diberikan konsumen kepada lembaga yang terlibat.

\section{a. Margin Pemasaran}

Analisis margin pemasaran merupakan salah satu indikator untuk menetukan efisiensi operasional pemasaran suatu komoditas. Margin pemasaran adalah perbedaan antara harga yang diterima petani dengan harga yang dibayarkan oleh konsumen yang meliputi seluruh biaya pemasaran selama proses penyaluran komoditas dari satu lembaga pemasaran ke lembaga pemasaran lainnya. Pada penelitian ini margin pemasaran dihitung berdasarkan ketiga saluran pemasaran. besarnya margin pemasaran kayu sengon dapat dilihat pada Tabel 8.

Tabel 3. Analisis margin pemasaran kayu sengon pada ketiga saluran

\begin{tabular}{|c|c|c|c|c|c|c|}
\hline \multirow{2}{*}{ Biaya } & \multicolumn{2}{|c|}{ Saluran I } & \multicolumn{2}{|c|}{ Saluran II } & \multicolumn{2}{|c|}{ Saluran III } \\
\hline & (Rp/m3) & $\%$ & (Rp/m3) & $\%$ & (Rp/m3) & $\%$ \\
\hline Petani & 600,000 & 32.43 & 700,000 & 39 & & - \\
\hline Pengumpul & 170,000 & 9.19 & - & - & _ & - \\
\hline 1. Tenaga Kerja & 50,000 & 2.70 & - & - & - & - \\
\hline 2. Bongkar Muat & 40,000 & 2.16 & - & - & - & - \\
\hline 3. Chainsaw & 30,000 & 1.62 & - & - & - & _ \\
\hline 4. Transportasi & 50,000 & 2.70 & - & - & - & - \\
\hline Margin Keuntungan & 130,000 & 7.03 & - & - & - & - \\
\hline Margin Pemasaran & 300,000 & 33.33 & - & - & - & - \\
\hline Harga Jual & 900,000 & 48.65 & - & - & - & - \\
\hline 1. Tenaga Kerja & 65,000 & 3.51 & 120,000 & 6.67 & - & _ \\
\hline 2. Bongkar Muat & - & - & 40,000 & 2.22 & - & - \\
\hline 3. Cinsaw & - & - & 30,000 & 1.67 & - & - \\
\hline 4. Pengolahan & 75,000 & 4.05 & 75,000 & 4.17 & - & _ \\
\hline 5. Transportasi & 60,000 & 3.24 & 110,000 & 6.11 & - & _ \\
\hline Margin Keuntungan & 400,000 & 21.62 & 425,000 & 23.61 & - & _ \\
\hline Margin Pemasaran & 600,000 & 40.00 & 800,000 & 53.33 & - & - \\
\hline Harga Jual & $1,500,000$ & 81.08 & $1,500,000$ & 83.33 & - & - \\
\hline Pedagang Kayu & 150,000 & 8.11 & 150,000 & 8.33 & - & - \\
\hline 1. Transportasi & 100,000 & 5.00 & 100,000 & 5.56 & _ & - \\
\hline 2. Bongkar Muat & 50,000 & 2.70 & 50,000 & 2.78 & - & - \\
\hline Margin Keuntungan & 200,000 & 10.81 & 150,000 & 8.33 & - & _ \\
\hline Margin Pemasaran & 350,000 & 18.92 & 300,000 & 16.67 & - & - \\
\hline Harga Jual & $1,850,000$ & 100.00 & $1,800,000$ & 100.00 & - & _ \\
\hline
\end{tabular}




\begin{tabular}{|l|c|c|c|c|c|c|}
\hline \multirow{2}{*}{ Biaya } & \multicolumn{2}{|c|}{ Saluran I } & \multicolumn{2}{c|}{ Saluran II } & \multicolumn{2}{c|}{ Saluran III } \\
\cline { 2 - 7 } & $\mathbf{( R p / m 3 )}$ & $\%$ & $\mathbf{( R p / m 3 )}$ & $\%$ & $\mathbf{( R p / m 3 )}$ & $\%$ \\
\hline APKAR & - & - & - & - & 470,000 & 31.3 \\
\hline 1. Penebangan & - & - & - & - & 50,000 & 3.3 \\
\hline 2. pengolahan & - & - & - & - & 170,000 & 11.3 \\
\hline 3. tranportasi & - & - & - & - & 250,000 & 16.7 \\
\hline Margin Keuntungan & - & - & - & - & 730,000 & 48.7 \\
\hline Margin Pemasaran & - & - & - & - & $1,200,000$ & 80 \\
\hline Harga Jual & - & - & - & - & $1,200,000$ & 80 \\
\hline \multicolumn{1}{|c|}{ PT PAL } & - & - & - & - & $1,500,000$ & 100 \\
\hline Total & $1,850,000$ & 100 & $1,800,000$ & 100 & $1,500,000$ & 100 \\
\hline
\end{tabular}

Tabel diatas menunjukkan bahwa besaran biaya pemasaran yang dikeluarkan oleh setiap lembaga pemasaran berbeda. Pada saluran 1 dan 2 petani tidak mengeluarkan biaya pemasaran karena biaya ditanggung oleh lembaga pemasaran selanjutnya sedangkan pada saluran 3 biaya pemasaran ditanggung oleh petani. Biaya pemasaran yang dikeluarkan oleh pedagang pengumpul yaitu biaya penebangan, bongkar muat dan transportasi. Biaya pemasaran pada industri penggergajian yaitu upah tenaga kerja, pengolahan, dan tranportasi. Sementara untuk pedagang eceran biaya yang dikeluarkan yaitu transportasi dan bongkar muat.

Margin pemasaran saluran 1 merupakan merupakan margin pemasaran terbesar dari ketiga saluran, yaitu sebesar $\mathrm{Rp} 1.250 .00 / \mathrm{m}^{3}$. Hal ini dikarenakan saluran pertama merupakan rantai pemasaran terpanjang dari ketiga saluran yang ada. Petani menjual kayu sengon ke pedagang pengumpul dengan harga $\mathrm{Rp}$ $600.000 / \mathrm{m}^{3}$. Petani tidak mengeluarkan biaya pemasaran karena biaya ditanggung oleh pedagang pengumpul sebesar Rp $170.000 / \mathrm{m}^{3}$. Selanjutnya pengumpul menjual ke pihak industri penggergajian dengan harga sebesar Rp. $900.000 / \mathrm{m}^{3}$ dengan keuntungan sebesar $\mathrm{Rp} 130.000 / \mathrm{m}^{3}$. Harga jual dari industri penggergajian ke pedagang pengecer sebesar Rp $1.500 .000 / \mathrm{m}^{3}$ dengan biaya pemasaran sebesar Rp $200.000 / \mathrm{m}^{3}$, sehingga keuntungan yang diperoleh sebesar Rp $400.000 / \mathrm{m}^{3}$. Pada tingkatan pedagang pengecer menjual kayunya dengan harga $\mathrm{Rp} 1.850 .000$ dengan besar biaya pemasaran $\mathrm{Rp} .150 .000 / \mathrm{m}^{3}$ dan memperoleh keuntungan sebesar Rp 200.000/ $\mathrm{m}^{3}$.

Pada saluran pemasaran 2, petani menjual kayunya ke industri penggergajian dengan harga $\mathrm{Rp}$ $700.000 / \mathrm{m}^{3}$, dengan biaya pemasaran ditanggung oleh pihak industri penggergajian. Biaya pemasaran yang harus dikeluarkan oleh pihak industri penggergajian sebesar Rp $375.000 / \mathrm{m}^{3}$ dan menjual ke pedagang pengecer dengan harga $\mathrm{Rp} 1.500 .000 / \mathrm{m}^{3}$, sehingga industri penggergajian memperoleh keuntungan sebesar $\mathrm{Rp}$ $425.000 / \mathrm{m}^{3}$. Selanjutnya pihak pedagang pengecer menjual ke konsumen dengan harga sebesar Rp $1.800 .000 / \mathrm{m}^{3}$ dengan biaya pemasaran sebesar $\mathrm{Rp} 150.000 / \mathrm{m}^{3}$ dan memperoleh keuntungan sebesar Rp $150.000 / \mathrm{m}^{3}$. Dengan demikian margin pemasaran yang terjadi pada saluran 2 sebesar Rp $1.100 .000 / \mathrm{m}^{3}$

Pada saluran pemasaran 3 memperoleh margin pemasaran terendah sebesar Rp $770.00 / \mathrm{m}^{3}$ petani menjual kayunya ke industri pengolahan kayu lanjutan dengan melalui mekanisme APKAR dengan biaya pemasaran ditanggung pihak petani. Harga jual kayu ke indutri pengolahan kayu lanjutan sebesar Rp $1.200 .000 / \mathrm{m}^{3}$ dengan biaya pemasaran sebesar $\mathrm{Rp} 470.000 / \mathrm{m}^{3}$, dengan demikian petani memperoleh keuntungan sebesar Rp. $730.000 / \mathrm{m}^{3}$.

\section{b. Analisis Rasio Keuntungan dan Biaya}

Rasio keuntungan dan biaya pemasaran merupakan nilai dari keuntungan yang diterima, dibandingkan dengan biaya pemasaran yang dikeluarkan oleh setiap lembaga pemasaran. Rasio keuntungan dan biaya pada masing-masing lembaga pemasaran kayu sengon dapat dilihat pada tabel di bawah : 
Tabel 4. Rasio keuntungan tiap saluran pemasaran

\begin{tabular}{|c|c|c|c|}
\hline Saluran pemasaran & $\begin{array}{c}\text { Keuntungan } \\
\mathrm{Rp} / \mathrm{m}^{3}\end{array}$ & $\begin{array}{c}\text { Biaya pemasaran } \\
\mathrm{Rp} / \mathrm{m}^{3}\end{array}$ & $\begin{array}{c}\text { Rasio keuntungan dan } \\
\text { Biaya }\end{array}$ \\
\hline Saluran 1 & 730.000 & 520.000 & 1.4 \\
\hline Saluran 2 & 575.000 & 525.000 & 1.1 \\
\hline Saluran 3 & 730.000 & 470.000 & 1.5 \\
\hline
\end{tabular}

Tabel 4 menunjukkan rasio keuntungan pada saluran pemasaran 1 sebesar 1.4, artinya setiap satu rupiah biaya pemasaran yang dikeluarkan akan memberikan keuntungan sebesar 1.4 rupiah. Farmer share yang diperoleh sebesar $32.43 \%$ dengan share keuntungan untuk masing-masing lembaga pemasaran yaitu pedagang pengumpul sebesar $17.8 \%$, industri penggergajian sebesar $54.8 \%$, dan pedagang eceran sebesar $27.4 \%$.

Rasio keuntungan dan biaya pada saluran pemasaran 2 sebesar 1.1, artinya setiap satu rupiah biaya pemasaran yang dikeluarkan akan memberikan keuntungan hanya sebesar 1.1 rupiah. Farmer share yang diperoleh yaitu sebesar $39 \%$ dengan share keuntungan lembaga pemasaran masing-masing industri penggergajian sebesar $74 \%$, dan pedagang pengecer sebesar $26 \%$.

Sementara rasio keuntungan dan biaya saluran pemasaran ketiga sebesar 1.5 rupiah. Hal ini berarti setiap satu rupiah biaya pemasaran yang dikeluarkan pada pemasaran memberikan keuntugan sebesar 1.5 rupiah. Farmer share yang diperoleh sebesar $47 \%$.

Berdasarkan hasil analisis rasio keuntungan dan biaya, saluran pemasaran 3 merupakan saluran yang memperoleh rasio keuntungan terbesar (1.5) dan saluran 2 yang memperoleh rasio keuntungan dan biaya yang terkecil (1.1).

\section{KESIMPULAN}

Saluran pemasaran petani APKAR yang terbentuk sebanyak tiga saluran yakni saluran 1: Petani Pengumpul - Industri sawmill - Pedagang Eceran, saluran 2: Petani - Industri sawmill - Pedagang Eceran, saluran 3 : Petani - APKAR - Industri pengolahan kayu (PT PAL). Berdasarkan pendekatan SCP (structur, conduct, and performance) sistem pemasaran kayu yang terdapat pada petani APKAR belum efisien oleh karena struktur pasar secara keseluruhan (cenderung ke Oligopsoni), kemudian perilaku pasar yang cenderung dikuasai oleh industri sawmill.

\section{DAFTAR PUSTAKA}

Alviya I. 2011. Efisiensi dan Produktifitas Industri Kayu Olahan Indonesia Periode 2004-2007 dengan Pendekatan Non Parametrik Data Envelopment Analysis. Jurnal Penelitian Sosial dan Ekonomi Kehutanan Vol. 8 No. 2, Hal 122-138.

Departemen Kehutanan. 2007. Road Map Revitalisasi Industri Kehutanan Indonesia In-House Experts Working Group Revitalisasi Industri Kehutanan. Jakarta (ID): Departemen Kehutanan.

Dwiprabowo H. 2009. Analisis Daya Saing Ekspor Panel-Panel Kayu Indonesia dan Malaysia. Jurnal Analisis Kebijakan Kehutanan Vol. 6 No.2, hal. 151 -160

Istoto YEB dan Listyanto T. 2009. Strategi Industri Perkayuan Nasional: Prioritas Rasionalisasi Teknologi Kayu Masa Depan. Prosiding Seminar Nasional Mapeki XII, hal. 1008-1014

Kotler P dan Armstrong G. 2008. Prinsip-prinsip Pemasaran Jilid 2 Edisi 12. BobSabran, penerjemah. Jakarta (ID): Penerbit Erlangga. Terjemahan dari:Principles of Marketing, Twelfth Edition 


\section{学}

Makkarennu dan Nakayasu. 2013. Prospective Indonesian Plywood in the Global Market. Journal of Life Sciences and Technologies Vol. 1, No. 3, hal. 190 - 195.

Rosnawati E. 2004. Karakteristik pemasaran kayu hasil hutan rakyat di Cianjur Selatan (Kasus di Kecamatan Cibinong dan Sindangbarang).Skripsi]. Bogor (ID): Institut Pertanian Bogor.

Tukan M, Dkk. 2000.Pemasaran Kayu Dari Lahan Petani Di Provinsi Lampung. World Agroforestry Center, ICRAF SE Asia, Bogor , Indonesia.

Widarti. 2015. Kontribusi Hutan Rakyat untuk Kelestraian Lingkungan dan Pendapatan. Pros Sem Nas Masy Biodiv Indon Vol 1 (7), hal. 1622-1626 